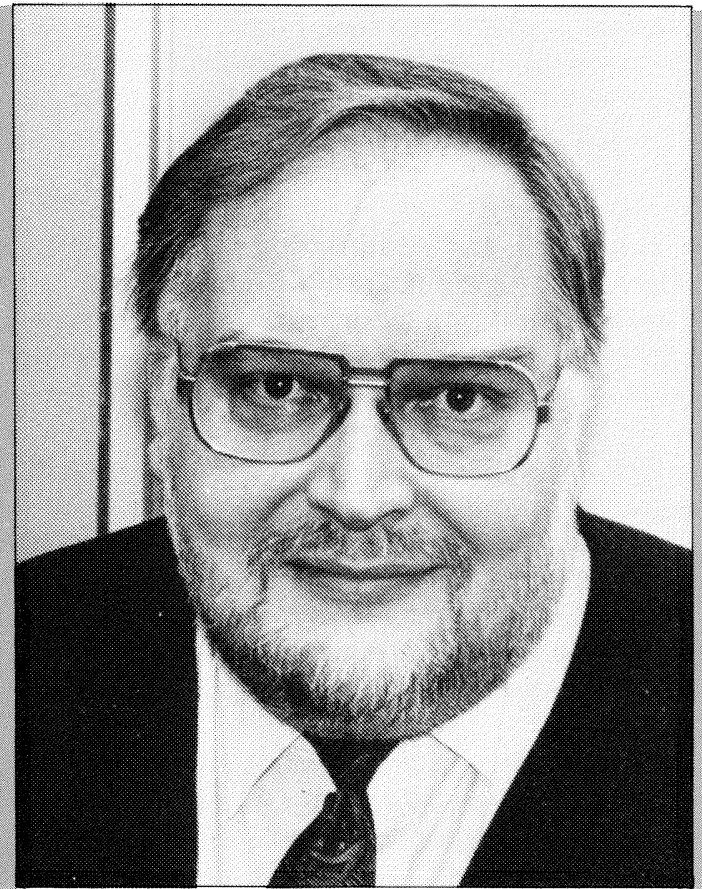

Opetusneuvos Olavi Alkion arviointi opintokeskuksista (Aikuiskasvatus 1/92) oli murheellinen. Tulevaisuus ja sitä kantava motivaatio näyttävät epäselviltä. Säästöä syntyisi, kun puolet opintokeskusten valtionavusta muutettaisiin suoraksi järjestöjen koulutustueksi. Opintokeskukset pienenisivät opintokerhojen ylläpitäjäksi.

On paradoksi, että samalla kun tietoyhteiskunnan tarpeet kasvavat räjähtäen vapaa sivistystyö näyttää häipyvän kuulumattomiin.

Viranomaisen käsitystä voisi lähteä kumoamaan vyöryttämällä tietoa ja kokemusta siitä valtavan monimuotoisesta opintotoiminnasta, joka kyliin ja kortteleihin hajautettuna opintokeskusten suojissa toimii. Tämä olisi myös perusteltua sittenkin osanottajaa kohti laskettuna edullisen aikuiskasvatuksen muodon puolustamista. Tuskinpa moni valtion 70 miljoonan markan panostus muuttuu niin runsaksi toiminnaksi niin monelle. Ilman opistokeskusten jäsentävää ja virittävää työtä valtaosa siitä sammuisi. Myös orna kokemus perustason työstä antaa kerta toisensa jälkeen hyvän olon.

Järeä perustelu on niin ikään opintojohtaja Tapani Rankin kirkkaasti esiin kehittämä näkemys siitä, miten opintokeskusten pieni tuki on kansanopistojen ohella itse asiassa ainut kasvatuksen sisäinen panostus kansanvaltaisen yhteiskunnan moniarvoisuuteen. Sen poistaminen veisi meidät rakenteellisesti takaisin bysanttiin, valtion siunaamaan yhtenäiskulttuuriin.

Silti puolustus ei kokonaan kumoa pettymystä, joka vapaaseen sivistystyöhön ja opintokeskuksiin kohdistuu. Perustajaisien tarkoituksena oli tehdä järjestöille eräänlainen Al Caponen tarjous, josta ei voi kieltäytyä. Pelisäännöt tehtiin niin hyviksi, että houkutteen turvin saattoi odottaa elävää, monimuotoista, ideoita ja toimintaa sykkivää sivistystyön uutta aaltoa.

\section{Opintokeskus jakokanavana}

Mistä sitten pettymys? Kyynikko saattaisi vastata, että mitä parempi valtionavun järjestelmä sitä varmemmin se tuhoaa kohteensa. Syntyy valtionavun kärttämiseen erikoistunut ammattikunta. Sävyä vahvistaa periaatteessa hyvää tarkoittava menoperusteisuus, joka käytännössä hukuttaa hyvänkin aloitteisuuden loputtomaan lippu- ja lappusotaan. 
Silti tämä ei ole koko- eikä edes päävastaus. Ongelmia kannattaa jäljittää myös järjestelmän rakenteeseen. Opintokeskus on perusluonteeltaan "tyhmä pääte", opintotoimintojen rahatuen jakojärjestelmä. Opintokeskuksen tuoma lisäarvo kohdistuu menoperusteisen valtionavun hallintaan, vähän tiedotukseen ja parhaassa tapauksessa aikuiskasvatuksen osaamiseen.

Opintokeskusten tämä muoto oli perusteltu aikana, jona valistettavan tiedon saattoi ajatella kompaktiksi kokonaisuudeksi (tiede, asiantuntija, oppikirja; järjestöjohto), jona ihmiset jäsentyivät järjestöalamaisiksi ja jona ideologialla oli pyhityksensä kiinteänä maailman jäsentämisen tapana.

Juuri näissä suhteissa viime vuosikymmenet ovat muuttaneet kaiken. Tiedon kasvu on räjäyttänyt kiinteän tietokäsityksen sekavaksi, paisuvaksi ja alituiseen muuttuvaksi tiedon myllerrykseksi. Silti alamaiset uskaltautuvat koulutustason nousun myötä ottamaan itse kantaa ja kantamaan kansalaisen vastuun. Suuret ideologiat ovat kuolleet, mikä ei vähennä aatteen merkitystä. Kehittyneessä kansanvallassa vain itse kukin muodostaa oman aatteensa.

Tämän kansalaisen palvelukseen pitäisi opintokeskustenkin vääntyä. Opintojen sisällön tasovaatimus kasvaa. Moniarvoisen yhteiskunnan arvoperustaiset opintokeskukset voisivat olla majakoita, joiden avulla kansalainen voi suunnistaa tiedon merellä myrskyävällä.

\section{Tutkimuksen ja tiedon ykseys}

Tavallisin keino selvitä tietoräjähdyksen jälkeisessä tietoyhteiskunnassa on ollut oma tutkimuspanostus. Lähes jokainen toiminta vaatii tänään toiminnan omiin tarpeisiin ankkuroituvaa tiedonhallintaa. Juuri tässä opintokeskukset ovat oman rakenteensa vuoksi jääneet ajastaan pahiten jälkeen. Vain KSL on ollut aallossa mukana - osin kait siksi että maassa on ollut niin elinvoimainen marksilaisen yhteiskuntatutkimuksen perinne. Muilla tutkimuspohjainen tiedon tuotanto jää muutaman idun ja enemmän tai vähemmän kunnianhimoisen aineistotuotannon varaan.

Tuloksena on ollut klassinen virhe, sama josta J. V. Snellman yliopistofilosofiassaan varoitti. Itse tiedon olemukseen kuuluu, että vain se, joka tutkii, voi myös opettaa.
Kun opintokeskuksilla ei ole omaa tiedon tuottamisen ja -hallinnan järjestelmää, se on tuomittu tulemaan toimeen satunnaisista lähteistä haetulla lainavalolla. Sen varassa ei luoda tietoyhteiskunnan vaatimaa sivistystyön profiilia. Tämä tuntuu otteettomuutena opintokeskusten arjessa. En kummastele, jos opetusviranomainen joskus kysyy ääneen toiminnan mielekkyyttä.

Lopputulemani on, että opintokeskusten aika opintotoiminnan valtionavun jakoapulaisena alkaa olla ohi. Silti en lopettaisi itse laitosta, etenkään nyt kun kansanopistotkin ovat koheltamassa vapaasta sivistystyöstä ammatillisen aikuiskasvatuksen avarille jos kohta kuivakkaille vainioille.

Opintokeskusten organisaatiot ovat muuttumisvalmis, nopealiikkeinen, herkkäviritteinen ja halpa sivistyksen eturintama. $\mathrm{Ne}$ on vain vapautettava tietoyhteiskuntaan. Tärkein vaatimus on, että opintokeskusten tai ainakin sivistysliittojen on voitava panostaa sen tiedon hallintaan, jota ne viljelevät.

Klassisen sivistysajatuksen mukaisesti opintotoiminnan tarvitsema tieto kumpuaa edelleen kahdesta lähteestä: ihmisen sisäistä kehitystä virittävästä sivistystyöstä ja yhteiskunnallisesta sivistystyöstä. Kumpaakaan ei pidä panna kilpailemaan samalla viivalla kaupallisen tai ammattipätevyyttä tuottavan tiedon kanssa.

\section{Vaativampaan sivistykseen}

Osa opintokeskusten perinteisistä tehtävistä pysyy tärkeinä. Kulttuurista, toiminnallista, harrastavaa ja elämänkatsomusta pohtivaa järjestäjää tarvitaan entistä kipeämmin nyt myös siksi, että $\mathrm{mm}$. kansalaisopistot ja kunnallinen kulttuuritoimi ovat vetäytymässä alalta. Näin käy erityisesti maaseudulla.

Opintokeskus on taide- ja harrastepohjaksi erinomainen. Se antaa pienin panostuksin toiminnalle jäsennyksen ja ryhdin, mutta ei kahletta. On vain saatava uusi elämys vapaan ja vapaaehtoisen sivistystyön merkityksestä.

Yhteiskunnallinen kasvatus on luettu vanhastaan osaksi vapaata sivistystyötä, myös siksi että yhteiskunnan harrastus tapaa herätä vasta aikuisena. Kouluikään sijoitettu kasvatus kantaa vettä 
kaivoon. Yhteiskunnallista tarjontaa pitäisi olla saatavilla silloin, kun aikuinen sitä tarvitsee.

Nytkin kymmenet polttavat kysymykset vaatisivat parempaa tai edes jonkinlaista ymmärtämistä: maapallon ekologia, vahva Suomi EY:n jäsenenä, lama, työttömyys, maakuntien tulevaisuus, kunnat valtionosuusuudistuksen jälkeen jne. Kaikkiin niihin latautuu tiedontarve, joka on kansanvallassa tärkeä. Nyt opintokeskukset ovat näissä asioissa yhtä ymmällä kuin muukin yhteiskunta ja niiden kyky palvella jäsenjärjestöjään on heiveröinen.

Muualla maailmassa sadat foundationit ja stiftungit muodostavat ajankohtaisia päätöksenteon kysymyksiä jäsentävän tiedonhallinnan työpohjan. Esimerkiksi Saksa sijoittaa pieneen Stiftung fur liberale Politik- säätiöön 100 miljoonaa DMK. Ruotsi suunnittelee niin ikään tutkimuksen tukemista ja panostavansa sivistysliittojen kautta EYpohdintaan 100 miljoonaa kruunua. Englannissa ja Yhdysvalloissa on useita arvopohjansa selkeästi ilmaisevia politiikan tutkimuksen laitoksia.

Meillä ei ole vastaavaa, ei ainakaan ennen kuin yhteiskunnallisia opintokeskuksia ylläpitävät sivistysjärjestöt ehtivät sellaisiksi kehittyä. Tarvetta korostaa vielä yhteiskuntatieteen lama. Suomalainen todellisuus vahvistaa taas kerran väitettä, jonka mukaan heikosta päästä kärsii koko ruumis. Omaan tiedontuotantoon kykenevät opintokeskukset voisivat olla pienen kansan tuki oman itsensä hallitsemisessa ja ohjaamisessa.

\section{Laskentapohjan ongelmat}

Menoperusteisella valtionavulla on omat perusteensa. Nyt järjestelmä on vanhentunut ja huvittavakin: sivistystyön pääkysymyksinä ovat loputtomat totiset kinat siitä, mikä lappu milloinkin on valtionavun alaista. Järjestelmä lukitsee toimintamuodot ja henkilöstön ahtaaseen muottiin. Eikä menoperusteisuus edes toimi: käytännössä opetushallinto määrittää yksiselitteisesti opintokeskusten toiminnan rajat.

Laskennallinen valtionapu ratkaisisi nämä pulmat, mutta laskentaperusteen kehittäminen ei ole helppo toimi. Sivistystyö oikeimmillaan on luovaa, monimuotoista, elävää, muuttuvaa ja ennakoimatonta. Mikä tahansa laskentaperuste tuntuu tarttuvan siihen vääristävästi. Esimerkiksi osallistujatunti on mahdoton mittari modernissa, myös etäopetuksen sisältävässä oppimisessa. Määrän ja laadun suhde on niin ikään ylikäymätön pulma toiminnassa, joka on hajautettu näkymättömiin kymmeniin tuhansiin pisteisiin. On laskentaperuste mikä tahansa, vaarana on, että voimakkaat organisaatiot tekevät siitä pelkän valtionapunsa kasvatuskeinon.

Hakijan taustajärjestöjen jäsen- tai äänimäärä on peruste sekin, mutta ainoana laskentapohjana sivistykselle outo suorite. En löydä jakoperustetta, joka ohittaa valistuneen harkinnan. Sitä varten meillä ovat valitut päättäjät. Oma ratkaisuni on yksinkertaisesti ns. könttämalli. Sen mukaan opetushallinto jakaa vapaaseen sivistystyöhön liikenevän tuen pitäen lähtökohtina (1) toimintaa säätelevän lain tarkoituspykälää, (2) anojan yleistä merkitystä, toimintakertomusta ja - suunnitelmaa sekä (3) kohtuullisesta odotusarvosta poikkeavia määrällisiä tietoja. Kontrolliksi riittävät kateus, tilintarkastus ja jäsenjärjestöt. 